Portland State University

PDXScholar

Business Faculty Publications and

Presentations

The School of Business

$11-2021$

\title{
Institutional Theory in Sport: A Scoping Review
}

\author{
Jonathan Robertson \\ Deakin University \\ Mathew Dowling \\ Anglia Ruskin University \\ Marvin Washington \\ Portland State University, marvin6@pdx.edu \\ Becca Leopkey \\ University of Georgia \\ Dana Lee Ellis \\ Laurentian University
}

See next page for additional authors

Follow this and additional works at: https://pdxscholar.library.pdx.edu/busadmin_fac

Part of the Sports Management Commons

Let us know how access to this document benefits you.

\section{Citation Details}

Robertson, Jonathan; Dowling, Mathew; Washington, Marvin; Leopkey, Becca; Ellis, Dana Lee; and Smith, Lee, "Institutional Theory in Sport: A Scoping Review" (2021). Business Faculty Publications and Presentations. 248.

https://pdxscholar.library.pdx.edu/busadmin_fac/248

This Post-Print is brought to you for free and open access. It has been accepted for inclusion in Business Faculty Publications and Presentations by an authorized administrator of PDXScholar. Please contact us if we can make this document more accessible: pdxscholar@pdx.edu. 
Authors

Jonathan Robertson, Mathew Dowling, Marvin Washington, Becca Leopkey, Dana Lee Ellis, and Lee Smith 


\section{Institutional Theory in Sport: A Scoping Review}

2 Institutional theory has generated considerable insight into fundamental issues within sport.

3 This study seeks to advance Washington and Patterson's (2011) review by providing an

4 empirical review of institutional theory in sport. We follow Arksey and O'Malley's (2005)

5 scoping review protocol to identify 188 sport related institutional studies between 1979 and

6 2019. Our review provides evidence regarding the state of institutional scholarship within sport

7 via an analysis of authorship; year; journal; methodology; method; study population; and use

8 of institutional constructs (legitimacy, isomorphism, change, logics, fields, and work). Rather

9 than a hostile takeover or a joint venture proposed in Washington and Patterson's (2011)

10 review, the relationship between fields is more aptly described as a diffusion of ideas. By

11 developing an empirical review of institutional studies in sport, we hope to expedite the

12 diffusion of ideas between the two fields and work toward realising the collective benefits any

13 future joint venture may bring.

14

15

Keywords: legitimacy, isomorphism, change, fields, logics, work

16

17 


\section{Introduction}

We can state, without hyperbole, that concepts from the institutional theory

perspective have become institutionalized in the sport management literature. Concepts such as isomorphism, institutionalization, legitimacy, and organizational fields dominate subsequent research in that area. Around the same time that Powell and DiMaggio's (1991) 'orange book' was released, early sport management scholars, led by Trevor Slack, started applying the concepts of institutional theory to the sport context. Since then, the neoinstitutional approach (Powell \& DiMaggio, 1991) has generated considerable insights into sport and has sought to explain fundamental issues within the field. These include what makes (sport) organizations so similar? Why do they adopt practices that are seemingly irrational? And how can we explain organizational change within sport organizations? Early institutional studies examined how institutional arrangements influence structure, design, and behavior of sport organizations (e.g., Kikulis, et al., 1992). This included explaining the shift from amateurism to professionalism within sport organizations and systems (e.g., O'Brien \& Slack, 1999). These studies addressed how sport organizations can navigate their institutional environments to survive. Emphasis here included how and in what ways sport organizations respond to institutional pressures (e.g., Slack \& Hinings, 1994).

More contemporary institutional research has challenged the underlying assumptions of neo-institutionalism and the deterministic viewpoint that actors are "cultural dopes" subject to the "iron cage" of institutional forces (Powell \& DiMaggio, 1991). Instead,

40 institutional scholars, including some sport management researchers, have turned their 41 attention to how actors are able to influence (i.e., create, maintain, and disrupt) institutional arrangements (e.g., Agyemang et al., 2018). This re-orientation towards agency has produced a raft of new institutional-related research in sport which has sought to examine how 
individuals and sport organizations are able to change or adapt their institutional environments (e.g., Nite \& Edwards, 2021).

Despite the continued contribution of institutional theory to sport, there remains definitional ambiguities surrounding the central concept of what constitutes an "institution". The term institution is homonymous. Ranging from narrow definitions of organizational types such as prisons or universities (i.e., equating institutions to organizations), to broader definitions such as "self-reproducing social order" which involves "cognitive, normative and regulative structures and activities that provide stability and meaning to social behavior" (Scott, 1995, p. 33). We adopted Greenwood et al. (2017) definition of institutions as "moreor-less taken for granted repetitive social behavior that is underpinned by normative systems and cognitive understandings that give meaning to social exchange and thus self-reproducing social order" (pp. 4-5). This broader view ensured our review encapsulated as much of the institutional-related sport literature as possible whilst delimiting it to organizational institutionalism (Greenwood et al., 2017). In adopting this definition, the purpose of the present study is to empirically review the use of institutional theory in sport literature. In doing so, we seek to review scholarship that has utilized institutional approaches to investigate phenomena in the empirical context of sport and provide recommendations for future research.

Periodically, institutional theorists have taken stock of the field to stimulate discussion and advance knowledge. In the mainstream literature this has often occurred in the form of key texts such as DiMaggio and Powell's (1991) 'orange book' or more recently Greenwood et al's $(2008 ; 2017)$ 'green books'. Within sport management these discussions have taken the form of narrative reviews of institutional theory and sport management research (Washington \& Patterson, 2011), and more specific discussions based on the development of specific constructs such as institutional work (Nite \& Edwards, 2021). Our 
scoping review complements these studies by offering the first empirical review of the institutional theory in sport literature. By reviewing the insights of 188 institutional theory studies in the context of sport since 1979, we hope to add to this literature via an exploration of the growth, breadth, and development of institutional theory in sport.

\section{Methods}

Scoping reviews enable researchers to review knowledge in a field by adopting a "systematic approach to map evidence, identify main concepts, theories, sources, and knowledge gaps" (Tricco et al., 2018, p. 467). More specifically, they allow researchers to determine the extent, nature, and range of evidence on a topic, and are particularly useful for summarizing findings within research domains characterized by a heterogenous body of knowledge (Tricco et al., 2018). Relative to other types of reviews such as meta-research (i.e., syntheses of existing reviews) and systematic reviews (i.e., exhaustive reviews of narrow content domains based on pre-established inclusion and exclusion criteria), scoping review protocols are particularly appropriate for developing a structured approach to mapping the broad field of institutional studies in the sport domain (Dowling et al., 2020) and were therefore selected for this study. This study adopted Arksey and O'Malley's (2005) scoping review protocol. Arksey and O’Malley outline a five-stage protocol (i) identification of research question, (ii) determination of relevant studies, (iii) study selection, (iv) charting the data, and (v) collating, summarizing, and reporting the results. We also adopted the Preferred Reporting Items for Systematic reviews and Meta-Analyses extension for Scoping Review (PRISMA-SCR) (Tricco et al., 2018) which provided a 20-point checklist for presenting scoping reviews.

\section{Identification of Research Question}

Our review sought to answer the following research question: How has institutional theory been employed within sport related studies? In particular, the project had three aims: 
94 (i) to investigate what is known about institutional theory within the empirical context of sport; (ii) to investigate how the use of different institutional constructs (i.e., institutional theory) within sport related literature has changed over time; and (iii) to identify potential future directions of research within institutional theory and sport related literature.

\section{Determination of Relevant Studies}

In August 2019, three electronic databases were searched (Scopus, Web of Science, SPORTDiscus) to ensure a comprehensive coverage of institutional studies in sport. The electronic database search terms "Institution*" AND "Sport*" (All-Fields) yielded a total of 3091 hits (Scopus $n=1302$, Web of Science $n=1515$, SPORTDiscus $n=274$ ). We further refined our search by focusing on peer-reviewed and English-language journal articles only. We also deliberately chose not to delimit our timeframe to ensure complete coverage of the literature. Consequently, all articles prior to August 2019, and those "in press" at this time, were included in our review. Through this process of refinement and once duplicates were removed, a total of 1995 articles were identified for further analysis.

\section{Study Selection}

To eliminate irrelevant studies, the research team developed explicit inclusion and exclusion criteria. Consistent with Arksey and O’Malley's (2005) protocol, these inclusion and exclusion criterion were developed post-hoc through an iterative process. In addition to the journal article and English language delimiters outlined above, an article was included if it utilized or engaged with concepts derived from organizational institutionalism (per Hall \& Taylor, 1996) or referred to new institutionalism (DiMaggio \& Powell, 1991) as opposed to alternate schools of institutionalism such as institutional economics and rational choice. This included any study which utilized core (e.g., isomorphism, legitimacy, logics, institutional/ organizational change, fields) or secondary (e.g., decoupling, deinstitutionalization, entrepreneur, hybridity, social movements, pluralism, materiality, leadership) institutional 
119 concepts identified within the SAGE Handbook of Organizational Institutionalism

120 (Greenwood et al. 2017). Delimiting studies in this way ensured that our final data set

121 included studies which utilized the theoretical, rather than normative use of the term

122 institution, which often describes organizational contexts (e.g., university, school, or

123 hospital), subsets of these contexts (e.g., institutional review board), or descriptions of

124 institutionalized persons (e.g., prisoners, mental health patients, aged care residents).

125 To ensure the reliability of the selection process, the first and second author

126 conducted an inter-coder reliability test on 100 articles from the SPORTDiscus database (first

127100 automatically sorted by relevance according to EBSCO Host's algorithm). This process

128 returned an initial result of $96 \%$ agreement, with only minor differences between reviewers

129 on the remaining $4 \%$ of citations that were rectified upon discussion. Following this, the first

130 four authors, then independently conducted a title and abstract review of citations to ensure

131 that they met the inclusion criteria. Through this process a total of 209 studies were selected

132 for full-text analysis. A further 50 studies were excluded upon an analysis of their full text,

133 leaving 159 studies in our database. We conducted a manual search of all reference lists of

134 these 159 studies identified in the database search to identify any additional citations that

135 were not captured in the initial search. This extra step identified 29 additional relevant studies

136 and took our final database to 188 studies.

\section{Charting the Data}

138 The next stage of the process involved charting and data extraction from the 188

139 citations identified from the search process. Data extraction was carried out using Microsoft

140 Excel and involved collecting the following information on all citations: author, publication

141 year, title, journal, journal type (i.e., sport or non-sport journal), abstract, study purpose,

142 research questions, study location, article type (i.e., empirical/non-empirical), methodology,

143 method, study population (e.g., national sport organizations), sport (e.g., football), use of 
144 theory (specific/general), core constructs (e.g., isomorphism), dynamics and processes (e.g.,

145 coercive pressures). The selection of these variables was based upon the research question

146 and overall aims. All articles were then randomly divided across the research team to extract

147 the relevant data. The research team also met regularly throughout this stage to ensure

148 accuracy and consistency of the data extraction process.

149 Collating, Summarizing and Reporting Results

150 A frequency and thematic analysis of the final database was then conducted.

151 Frequency analysis is a descriptive statistical method that shows the number of occurrences

152 for each variable. This analysis primarily focused on publication frequency by year,

153 publication by journal, and geographical distribution of studies. We ran frequency analyses

154 for publication by authors, study population, type of sport, article types and methods. We

155 were also particularly interested in how institutional concepts had been adopted and utilized

156 within the sport literature, so we ran frequency analyses of constructs over time. For our

157 thematic analysis, we structured our review around the five core constructs (or tenets)

158 identified by Washington and Patterson (2011): legitimacy, isomorphism, fields,

159 organizational change, and logics. This enabled us to make direct comparisons about how the

160 use of institutional theory in sport had changed over time. Additionally, the research team

161 were also conscious of ensuring that we fully captured the use of any new concepts or recent

162 developments that emerged within mainstream management and sport literature. For this

163 reason, we added a sixth construct (institutional work and entrepreneurship), which emerged

164 as an increasingly influential area of research both within the mainstream and sport

165 management literature (Nite \& Edwards, 2021). The next section presents the frequency and 166 thematic analyses in full. 


\section{Findings and Discussion}

\section{Descriptive Analysis}

The analysis yielded a comprehensive framework from which to describe the state of

institutional theory in sport. The findings indicated that 229 researchers had (co)authored 188 studies since 1979. Indicative of the growth of the field, and institutional theory itself, over half $(54 \%)$ of these studies have been published since 2013 . Three in four studies $(76 \%)$ were located within sport journals, with the Journal of Sport Management (31, 17\%); Sport Management Review (24, 13\%); European Sport Management Quarterly (15, 8\%); and International Review of the Sociology of Sport $(12,6 \%)$ the most prominent. The remaining studies mainly appeared in mainstream management literature with the most common journals identified as Academy of Management Journal (4), Organization Studies (3); and

180 Canadian Journal of Administrative Sciences (3). The most prolific researchers were identified as Trevor Slack (19), Marvin Washington (11), Eivind Skille (10), and Bob Hinings (10).

Nine in ten studies that utilized institutional theories were empirical $(168,89 \%)$, rather than conceptual or non-empirical (20,11\%). Qualitative methodologies were the most prominent within empirical studies $(128,76 \%)$; followed by quantitative $(21,13 \%)$; and mixed methods (19, 11\%). Document analysis (41\%), interviews (36\%), observations $(9 \%)$ and questionnaire/survey $(6 \%)$ were the most frequently employed qualitative methodologies. Institutional theories were applied relatively evenly across a range of organizational contexts including national sport organizations $(33,18 \%)$; clubs $(30,16 \%)$; universities (primarily in

190 the United States; 25, 13\%); international federations (18, 10\%); and leagues $(15,8 \%)$. A

191 propensity for researchers to investigate multiple organizational contexts $(32,17 \%)$ within a single study was also noteworthy, in part due to the investigation of underlying social structures common within the institutional perspective. 
194

195

196

197

198

199

200

201

202

203

204

\section{Institutional Constructs}

Three-hundred-and-six institutional constructs were utilized within the 188 studies identified in our population, averaging 1.6 constructs per study. Building on the work of

Washington and Patterson (2011), the most applied constructs were change (77);

legitimization (including [de]institutionalization) (73); isomorphism (49); logics (46); work (including entrepreneurship) (26); fields (27); and other (i.e., translation, leadership, decoupling) (8). Figure 1 outlines the relative usage of constructs over time (i.e., the percentage of studies that used a construct to that point in time).

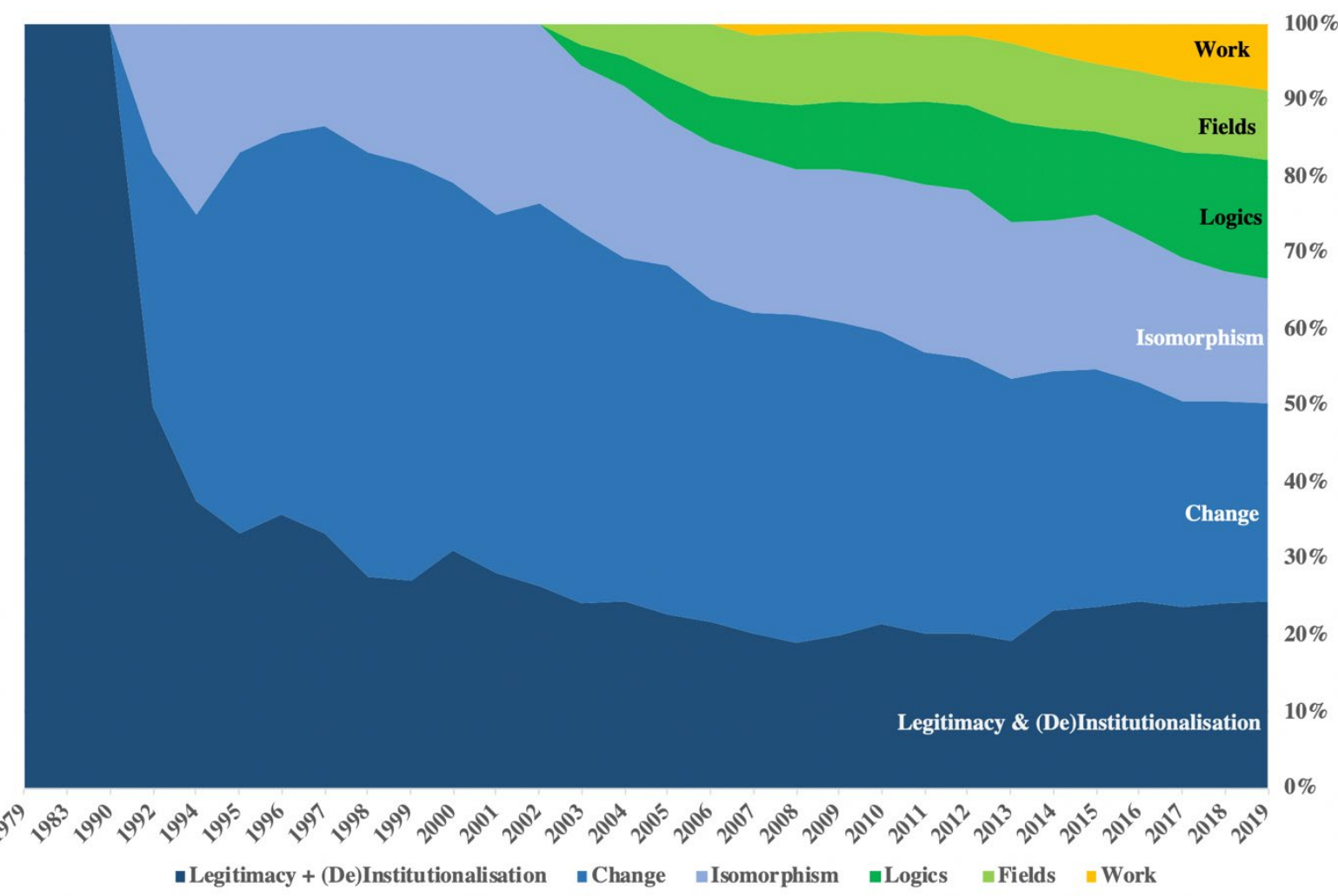

The first generation of constructs in blue consisted of legitimization, change and isomorphism and were the foundational constructs upon which neo-institutionalism developed in mainstream management and sociological discourses from the late 1970s to the mid-1990s (e.g., DiMaggio \& Powell, 1983; Meyer \& Rowan, 1977). This group of constructs accounted for all studies in our analysis until the mid-2000s. The second generation of constructs consisted of logics and fields (e.g., Friedland \& Alford, 1991; 
209 Thornton \& Ocasio, 1999). These views came to prominence within the sport management

210 literature in the mid-2000s to explain issues of competing logics within predefined areas of

211 organizational life. They also spawned several sub-domains including complexity, pluralism

212 and hybridity that are becoming more common in the literature. The third and final

213 generation picks up on the agency turn in institutional scholarship that broadly encompasses

214 notions of institutional work and entrepreneurship (DiMaggio, 1988; Lawrence \& Suddaby,

215 2006). These constructs focus more on the links between institutional structures and agency

216 to better understand how agents (e.g., individuals, organizations) can influence the creation,

217 maintenance, and disruption of institutions.

218 Figure 2 presents the six constructs of institutional theory developed by Washington

219 and Patterson (2011) and Greenwood et al. (2008). In addition, we extend on their work by

220 incorporating contemporary reviews and sub-classifications of each construct to help us, and

221 the field, conceptualize the broad domain of institutional theory in sport (e.g., Durand \&

222 Thornton, 2018; Micelotta et al., 2017; Suddaby et al., 2017). We do not claim or assert the

223 relative propriety of these frameworks in comparison to the multitude of others available,

224 however, we look to these works as effective conceptual tools to organize our thinking and to

225 demonstrate the scope of the field. Each construct will be discussed below.

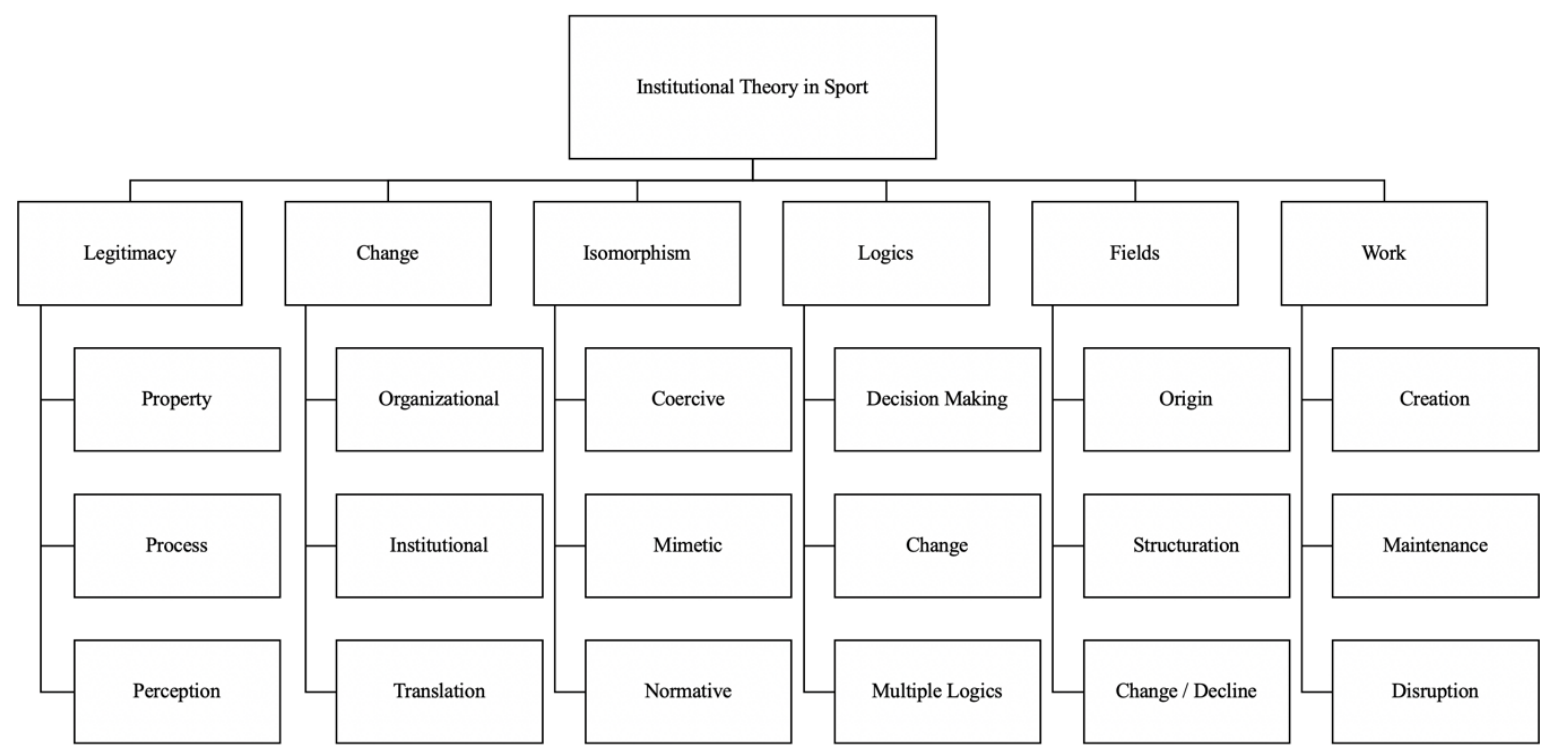




\section{Legitimacy and Institutionalization}

Our analysis revealed forty-one studies that investigated legitimacy. Organizational

legitimacy can be defined as "the perceived appropriateness of an organization to a social system in terms of rules, values, norms, and definitions" (Deephouse et al., 2017, p. 32).

Whilst the literature has identified many types of legitimacy (e.g., pragmatic, moral, cognitive), we draw from the legitimacy review study conducted by Suddaby et al. (2017) that identified three sub-research domains: legitimacy-as-property (i.e., as something an organization owns); legitimacy-as-process (i.e., socially constructed via interactions between actors); and legitimacy-as-perception (i.e., a collective social judgement or evaluation). explain a wide range of settings including the regulatory legitimacy of new lifestyle sports (e.g., Batuev \& Robinson, 2018) and the utility of legitimacy to attract funding, support policy goals, and to provide governance oversight (e.g., Stenling \& Sam, 2017). When viewed as a process, legitimacy studies have investigated the legitimation processes of various sport leagues, associations, and regulatory bodies (e.g., Read et al., 2019). Finally, a small but promising area of research has investigated perceptions of legitimacy. Particularly noteworthy here is the development of a framework that identified six themes that influenced how stakeholders perceive the legitimacy of a sport organization: role in community, staff and organizational behavior, valuing community, development approach, local players, and trialling procedures (Lock et al., 2015).

248 Rowan, 1977). From this perspective, institutionalization can be thought of as a "specified

249 process of the social construction of value and the attainment of legitimacy... where certain

250 practices can be seen as the only natural way of action" (Washington \& Patterson, 2011, p.

251 5). Our analysis identified twenty-one studies that specifically investigated a form of 
252 institutionalization. For example, the institutionalization of governance and control structures

253 (Kikulis, 2000); or anti-ambush marketing legislation within the Olympic movement (Ellis et al., 2016). Eleven further studies investigated deinstitutionalization (i.e., the reversal of institutionalization processes) and were particularly prevalent in early institutional change studies (e.g., O’Brien \& Slack, 1999). An inherent difficulty in institutionalization studies is the description of a program or structure that has, or is becoming, taken for granted or the natural way of action. Consequently, many studies couple institutionalization as a point of reference for historical activity that has subsequently been challenged or changed.

Change

Seventy-seven studies were identified in our review that broadly related to change.

262 Although we recognize their overlap, studies were categorized into three indicative areas: organizational change $(\mathrm{n}=26)$; institutional change $(\mathrm{n}=44)$, and translation $(\mathrm{n}=7)$.

\section{Organizational change}

The first generation of change research grew out of an attempt to understand how the institutional environment influenced the structure, design, and values of sport organizations (e.g., Amis et al., 2004) (n=19). This body of research utilized design archetypes as representations of organizations (e.g., Kikulis et al., 1992), and plotted these archetypes against change tracks to determine the "incidence, nature and cause of movements and the absence of movement between archetypes" (Greenwood \& Hinings, 1988, p. 303). The cumulation of this work was a more nuanced theoretical understanding of differences in the

272 pace (initially quick, then slower), sequence (initially high-impact areas such as the board),

273 and linearity (or more accurately non-linearity of change involving "oscillations and

274 reversals") of organizational change (Amis et al., 2004). A second group of studies utilized Pettigrew's (1987) contextualist approach to understand change based on content, context, and process $(\mathrm{n}=4)$. This viewpoint offered a strong grounding in the external conditions for 
277 change to help explain organizational change in transforming societies, or broad shifts in

278 national sport systems (e.g., Girginov \& Sandanski, 2008). The final subset of studies built on 279 Laughlin's (1991) models of rebuttal, reorientation, colonization, and evolution to explain 280 organizational change $(n=3)$, drawing from more critical forms of inquiry to surface internal 281 complexities and tensions in the change process (e.g., Zakus \& Skinner, 2008).

\section{Institutional Change}

283 Institutional change is broadly understood as differences in the "form, quality, or state over time in an institution... [between] two or more points in time on a set of dimensions typology developed by Micelotta et al. (2017) that consists of: displacement, alignment, accommodation, and accretion, to classify the institutional change literature. Displacement studies investigate how institutions change when one set of institutional frames, norms, rules, or logics, are displaced by another $(\mathrm{n}=7)$. Within sport, this included how professionalism displaced amateurism in English cricket organizations (e.g., Wright \& Zammuto, 2013), or how cultures of similarity were challenged by diversity initiatives (e.g., Cunningham, 2009). Alignment research $(n=19)$ has investigated how "institutional entrepreneurs embed changes into existing institutions and how macro-environmental evolutions can entail gradual and piecemeal institutional transitions" (Micelotta et al., 2017, p. 1901). For example, as societal norms and expectations changed toward concussion (e.g., Heinze \& Lu, 2017); pay (e.g., Wright \& Zammuto, 2013); and intercollegiate sport (e.g., Nite et al., 2019); powerful organizational actors worked to align their institutional fields with these changes to preserve the prevailing institutional structure. In fragmented and contested domains, forms of accommodation may occur between challengers seeking "to profoundly reconfigure the redistribution of material and symbolic resources" and incumbents who benefit from the existing arrangements and seek to protect their position (Micelotta et al., 2017, p. 1902) 
302 ( $n=6)$. Studies have demonstrated the complex stakeholder environments in sport necessitate

303 accommodation (e.g., Pedras et al., 2020) and can turn to innovative ideas such as the

304 development of a separate shareholding company to accommodate competing logics within a

305 single organization (Skirstad \& Chelladurai, 2011). Finally, an emerging area of institutional

306 research investigates the accretion of "bottom-up", "uncoordinated", or the "amplification of

307 micro-level interactions" that can lead to transformational institutional change $(\mathrm{n}=3)$. For

308 example, changes in sport participation (Borgers et al., 2019); discursive practices between

309 institutional entrepreneurs and defenders (Lakshman \& Akhter, 2015); and the "unintentional

310 coproduction" embedded in the everyday organizational life of sport organizations (Fahlén \&

311 Stenling, 2019) can all, over time, lead to substantive institutional change.

312 Translation

313 Translation primarily investigates how ideas travel $(\mathrm{n}=8)$. The concept is broadly

314 defined as when "new ideas are combined with already existing institutional practices and ...

315 involves the combination of new externally given elements received through diffusion as well

316 as old locally given ones inherited from the past" (Campbell, 2004, p. 80). The concept of

317 translation has been used in a relatively specific manner in sport studies. Predominately by

318 Scandinavian scholars to investigate how sport policies and programmes from central

319 formulators are translated and applied by implementors in local contexts (e.g., Skille, 2011).

320 Isomorphism

321 Generally, isomorphism refers to the notion that institutionalized ideas can influence

322 organizations to embrace structures and forms that resemble other organizations in the field

323 and as a result become increasingly similar (DiMaggio \& Powell, 1983). More specifically, it

324 has been argued that "organizations increasingly become isomorphic [i.e., similar] over time

325 as they collectively incorporate templates for organizing from their institutional environment

326 in search of legitimacy" (Heugens \& Lander, 2009, p. 61). However, this process assumes 
327 that adopting these specific practices will help provide a competitive advantage for the organization (i.e., adoption $=$ survival) when in reality this notion is a myth (Meyer \& Rowan, 1977). Forty-nine studies in this analysis considered isomorphism in their research. Several moderating field level influences on isomorphic processes have been identified. For example, DiMaggio and Powell (1983) detailed three generic isomorphic

332 pressures that can lead organizations to become increasingly similar (mimetic processes,

333 normative pressures, and coercive isomorphism). Mimetic processes are often caused by uncertainty (ambiguous goals or environmental) and during these times, organizations will try to copy or imitate others who are seen as successful or legitimate (DiMaggio \& Powell, 1983). Normative pressures on the other hand are associated with the adoption of practices or structures concerning what is generally considered to be a proper course of action within a

338 particular field (e.g., professionalization) (Greenwood et al., 2008). Finally, coercive isomorphism is the product of power relationships and politics. Often, it results from "both

340 formal and informal pressures exerted on organizations by other organizations upon which

341 they are dependent and by cultural expectations in the society within which organizations

342 function" (DiMaggio \& Powell, 1983, p. 150). Many of the studies in this review (n=31) that 343 applied isomorphism as a main construct also discussed the impacts of all three pressures. For example, Slack and Hinings (1994) used the concept of isomorphism and related institutional pressures to explore the emergence of professional and bureaucratic organisational structures in Canadian national sport organizations. On the other hand, some studies referred to the

347 generic isomorphic pressures without specifically discussing isomorphism as a core construct 348 (n=4). Leopkey and Parent (2012) for example, used DiMaggio and Powell's (1983) three generic pressures to describe how the concept of event legacy became institutionalized within the Olympic Movement. Twelve studies utilized isomorphism as a core construct but did not

351 detail the isomorphic processes involved. 


\section{Logics}

The concept of institutional logics emerged and evolved in response to common concerns within organization studies generally, and neo institutionalism specifically (e.g., agency, bounded rationality, and disproportionate attention on both mimetic isomorphism and the structural influence of organizational fields) (Durand \& Thornton, 2018). Thornton and Ocasio (1999) defined institutional logics as "the socially constructed historical patterns of cultural symbols and material practices, assumptions, values, and beliefs by which individuals produce and reproduce their material subsistence, organize time and space, and provide meaning to their daily activity" (p. 804). Ultimately, logics are understood as guiding principles that are both influenced by, and have an influence on, the behavior of actors and organizations within social and institutional contexts. It is this (i.e., Thornton \& Ocasio, 1999) approach to logics, alongside that of Friedland and Alford (1991), that guided the majority of the forty-six studies in this review.

We structure our review of logic studies in sport by combining areas of focus identified in Durand and Thornton's (2018) review and those of Lounsbury et al., (2017). Together these studies observe that research on logics tends to cover three key areas: logics and decision-making, changing logics, and dealing with multiple institutional logics.

\section{Logics and Decision-making}

Fundamentally, logics are understood as a frame for organizational decision-making and action. While some studies have specifically examined this relationship, fewer have focused here compared to the other two areas. Those that have, largely concentrated on the differing impact of multiple logics. For instance, Southall et al. (2008) examined how the dual logics of education and commercialism impacted the television representation of the National Collegiate Athletic Association's (NCAA) "March Madness" basketball event. In doing so, they found that the education logic had very little influence on related strategic 
377 decision-making, while the dominant commercial logic directly impacted strategic choices

378 related to television production. They argued this supports the contention that even when

379 multiple logics were present, a dominant logic held a greater influence on decision-making,

380 while other logics may exist purely for "ceremonial conformity" (p. 694) in aid of legitimacy.

\section{$381 \quad$ Changing Logics}

382 Despite the stability often associated with institutions, the idea that logics emerge and

383 evolve over time in response to various social and institutional pressures is central to our

384 understanding of logics (Thornton \& Ocasio, 2008). As such, changing logics is among the

385 most prominent and enduring elements of logics research in both mainstream- and sport-

386 management literatures. Researchers have centred their examinations on the antecedents of,

387 and organizational responses to, changing logics and the consequences of those changes on

388 organizations. With respect to antecedents, studies have identified a variety of internal and

389 external, actions, forces and pressures that have influenced change (e.g., Borgers et al., 2018).

390 Organizational responses to, and consequences from changing logics have also received

391 attention. Nite (2017) for instance examined how the NCAA used media message framing to

392 undertake the institutional maintenance work to protect existing logics in response to external

393 pressures for change. Finally, some studies in this area have specifically addressed a call for

394 research by Washington and Patterson (2011) on the dynamics of creating and changing

395 logics in field level institutions. Hemme and Morais (2021), for example, identified and

396 described five rhetorical strategies used by the National Parks and Recreation Association to

397 develop and promote the field-level logic of public recreation in the United States.

398 Dealing with Multiple Institutional Logics

399 Greenwood et al. (2017) argue that "understanding how organizations cope with

400 multiple logics is a priority in institutional research because scholars acknowledge that such

401 plurality is rather the norm than the exception" (p. 11). The importance and pervasiveness of 
402 multiple logics is reflected in the fact that many logic studies identified here considered

403 multiple logics. Organization can exist within more than one institutional sphere

404 simultaneously, and are consequently faced with negotiating multiple, pluralistic logics.

405 Institutional complexity subsequently arises out of the existence of pluralism and generates

406 varied responses to coping with conflicting and competing logics, such as hybrid forms of

407 organizing (e.g., Svensson, 2017). The exploration of responses to institutional complexity

408 was found to be central to the sport literature (e.g., Pedras et al., 2020). In particular, the

409 strategies of structural differentiation, or compartmentalization and effective leadership,

410 cultural buy-in, and stakeholder management were noted (e.g., Skirstad \& Chelladurai, 2011).

411 Finally, researchers in sport have taken a closer look at the impact (real or hypothetical) of

412 specific sets of circumstances on the tensions between multiple logics at both the

413 organizational and field level. For example, Pedras et al. (2020) found that the threat of

414 insolvency "coalesced tension and compatibility between logics" (p. 494) at Triathlon

415 Australia, whilst Agyemang et al. (2018) found that tensions between competing logics were

416 eased by the perception of having to maintain an institution in response to a threat.

\section{$417 \quad$ Fields}

418 Fields are arguably the central organizing concept of institutional theory, Scott (2014)

419 suggests their understanding and use continues to be both "widely accepted and hotly

420 contested" (p. 219). The conceptual focus in sport studies seemingly revolves around the

421 formative definition of fields put forward by DiMaggio and Powell (1983) and supported by

422 Bourdieu's (1990) foundational notion of field. Of the 27 studies identified as directly

423 engaging with the concept of fields, 18 provided a clear definition of fields and of those, 16

424 utilized DiMaggio and Powell's conceptualization to guide their understanding, while seven

425 of those also explicitly engaged with Bourdieu's concept of field. Kitchin and Howe (2013) 
426

427

428

430

431

432

433

434

435

436

437

438

439

440

441

442

443

444

445

446

447

448

449

450

provided a review of how elements of Bourdieu's practice theory (namely habitus, capital, and most importantly field) could be integrated into sport management research.

DiMaggio and Powell (1983) define organizational fields as "those organizations that, in the aggregate, constitute a recognized area of life: key suppliers, resource and product consumers, regulatory agencies, and other organizations that produce similar services or products" (p. 148). Washington and Patterson (2011) argued that "research in the organizational field tradition is one of the places where the research in institutional theory has moved faster than the research in the sport related institutional theory tradition" (p. 7). In the years since their seminal study, we have seen more sport studies focusing on fields. But with only 16 studies having been published since 2011 the increase has not been substantial. Scott (2014) argued that "some of the most important organizational scholarship of the past four decades has examined the origin, structuration, and change and/or decline of organization fields" (p. 223). With this in mind we used these categories to frame our discussion of sport studies that have utilized fields as their focal unit of analysis.

\section{Origin}

Consideration of the origins of institutional fields was found to be an area of research that is underrepresented in sport studies. While this could be related to conceptual overlap between origin, structuration, and change, with the focus of more studies falling under the latter two, this is nevertheless a gap in the research. This gap is important as empirical examinations of field origins could arguably provide a foundational depth of understanding that would contribute to other institutional work in that field as well as offering practical insights (Washington \& Ventresca, 2008). In this review, only three studies were notable for a clear focus on understanding how, why, and/or under what conditions a field comes to exist in a way that is definable. For example, Washington and Ventresca (2008) explored the origin of the field of US college athletics, whilst Hoibian (2006) adopted a historical narrative 
approach to examine both the genesis and institutionalization of the field of mountaineering by "analyzing the origin and developmental conditions of [the] social setting" (p. 341).

\section{Structuration}

DiMaggio and Powell (1983) emphasize that "fields only exist to the extent that they are institutionally defined" (p. 148) and it is this process of definition that we understand as structuration. Scott (2014) further notes that in organizational fields structuration can be referred to as "the extent of interaction and the nature of the inter-organizational structure that arises at the field level" and more broadly, the activities that produce and reproduce these social structures (p. 235). Within sport we see studies that examine many elements of field structuration. For example, Wright (2009) introduced the notion of fields as "nested" within one another, like a Russian Babushka doll, scrutinizing institutional change and formation via the interplay of societal, field, and organizational mechanisms. This same mechanism was then also adopted to examine multilevel (i.e., field) institutional change in the International shaped by pressures coming from the top-down (i.e., from society to field) and from the bottom-up (i.e., organizations influencing the broader field). structuration was also identified. Wright and Zammuto (2013) also added a horizontal element to field structuration by investigating social positions relative to a central value system (or logic) identifying central, middle status, and peripheral actors' roles in multilevel institutional change in English county cricket. Similarly, Washington (2004) considered how the NCAA, as a powerful interest association central within the field of US collegiate athletics, challenged the National Association of Intercollegiate Athletics to maintain dominance and control over field structuration. 


\section{Change and Decline}

Change in institutional fields was found to be the most widely adopted area of field research within sport studies. In addition, as has been noted, there is broad overlap between examining change and structuration, meaning that many of the studies discussed in the previous section could also be discussed here and vice versa. Alternatively, no studies were identified as focusing on the decline of a field, signalling a key future research opportunity. Principally, studies that considered field change looked at the process of change, the nature and extent of change, and/or influences affecting change, although like the broader categories many studies cover more than one of these areas. Among the most broadly cited sport studies on the nature and extent of field change comes from Cousens and Slack's (2005) analysis of the field of North American major league professional sport. They investigated changes in four facets of the field over time, specifically: "communities of actors, their exchange processes, their governance structures, and their beliefs and institutional logics of action" (p. 13). They found that a shift in dominant logics from embracing sport specific qualities, to stressing the entertainment value of major league sport, resulted from changing governance models brought about primarily by the deregulation of cable television.

A final group of studies on field change bring attention to the influences that can

493 affect organizational change. Batuev and Robinson (2018) for instance identified three

494 influences that framed the evolution of the field of skateboarding: the symbolic importance traditional non-competitive values, expanding commercial opportunities for professionalism and sponsorship, and the perceived impacts (both positive and negative) of entrance into the

497 Olympic movement. In looking at field level change in English Rugby Union, O’Brien and 498 Slack (2003) concluded that "a shift in the field's dominant logic is promoted, and indeed was prompted by a widespread change in its other components; notably, its communities of actors, exchange processes, forms of capital, and regulatory structure" (p. 443). 


\section{Institutional Work and Entrepreneurship}

One concept which has gained notable traction within institutional scholarship in the

last decade is institutional work. The perspective emerged from two broader literature bases that emphasized the ability of individuals to shape institutional arrangements (DiMaggio, 1988), and the sociology of practice tradition which examines how individuals manage and influence day-to-day activities (Bourdieu, 1977). Institutional work challenges the traditional

507 neo-institutional assumptions of structural determinism, and the notion that actors are

508 'cultural dopes' at the whim of institutional arrangements. In their seminal work, Lawrence and Suddaby (2006) define institutional work as "the purposive action of individuals or organizations aimed at creating, maintaining and disrupting institutions" (p. 215) and outline

511 various forms of institutional work. Since then, the perspective has "evolved from a concept

512 introduced to capture a set of actions described in institutional research, to a perspective on

513 the relationship between institutions and actors associated with a distinctive set of questions,

514 assumptions, findings and theoretical claims" (Hampel et al., 2017, p. 558). This shift is

515 apparent from the notable scholarly attention that has been dedicated to institutional work

516 within sport management over the past decade (Nite \& Edwards, 2021).

517 Our analysis identified 16 studies which explicitly adopted the institutional work

518 perspective. Consistent with the mainstream management literature, these studies have

519 predominantly focused on organizational and field-level institutional arrangements and have

520 explored various research contexts including governing agencies (Dowling \& Smith, 2016),

521 sport clubs (Lok \& de Rond, 2013), sexual abuse (Nite \& Nauright, 2020), and mixed martial 522 arts (MMA) organizations (Helms \& Patterson, 2014; Woolf et al., 2016). We structure our

523 review of this body of works by utilizing Lawrence and Suddaby's original categorizations: creation, maintenance, and disruption. 
Institutional work represents a fundamental departure from traditional institutional sport scholarship that predominantly emphasized the influence of changing institutional pressures on sport organizations (e.g., Slack \& Hinings, 1994). More recent studies have begun to focus on how actors are able to create institutional arrangements. For example, Helms and Patterson (2014) analysis of MMA organizations demonstrated how actors were able to utilize stigma, negative labels, and narratives created by others to attract audiences and increase the popularity of the sport. Similarly, Woolf et al. (2016) provided a micro-level account of how the sport of MMA developed within a training facility in Canada. Their analysis extended on Lawrence and Suddaby's original framework by identifying refinement and barrier work which Woolf et al. (2016) suggest both simultaneously helped grow, and hinder, the development of the sport. Both studies revealed the paradoxical role that institutional entrepreneurs - actors who create or transform institutional arrangements - can play in disrupting the very institutions they have sought to create.

\section{Maintenance}

Maintenance work refers to how institutions are maintained by actors to ensure institutional stability. Both Lawrence and Suddaby's original review of institutional work and

543 Washington and Patterson's (2011) review of institutional theory in sport highlighted the need for more studies specifically within the area of maintenance. Our review suggests that much work has now been done within this area. Lok and de Rond (2013) explained how

546 highly institutionalized practices are maintained by micro-level processes. Employing a year-

547 long ethnographic case study of one of the oldest sporting institutions, the Oxford-Cambridge

548 University Boat Race, the authors demonstrated that institutions contain a degree "plasticity" whereby institutional scripts "are stretched to accommodate ever-changing practice performance" (p. 186). Other studies have focused on how key sporting agencies maintain 
551 their dominance within organizational fields. For example, the historical and longitudinal

552 analysis conducted by Nite et al. (2019) revealed how the NCAA maintained its dominance through boundary work, adjustment of its own practices, and control of cognition (i.e., how other actors understood collegiate sport).

\section{Disruption}

Our analysis indicated that there were few studies that explicitly focused on actors' attempts to disrupt institutions within sport. This finding is consistent with Lawrence and Suddaby's (2006) assertions that empirical studies of institutional disruption and

that examined how actors employed maintenance work to respond to attempts to disrupt institutional arrangements in the case of Tommie Smith and John Carlos' silent protest at the 1968 Olympic Games. Although strictly speaking not a disruptive study, the analysis demonstrates how actors at the micro-level respond to other actors' attempts to disrupt an institution. Of note, the authors highlight the institutional complexity and the inter-play between several competing logics which can be temporarily produce what they described as an "institutional cease-fire" (p. 576).

We suggest that more work is needed within this specific area to understand how actors attempt to disrupt institutions. Agyemang et al. (2018) recognized this in their conclusionary remarks, "despite their role within change, we know very little about those who defy institutional rules and norms in an attempt to highlight a given cause" (p. 578). This is particularly surprising given that sport provides a rich context in which there are many highly visible attempts to disrupt arrangements. Recent examples include Colin Kaepernick's

573 kneeling to the national anthem in response to racial prejudices and injustices, national boycotts of mega-events, and individual athlete and state-sponsored doping violations. We suggest that institutional theory has much more to offer in terms of being able to explain both 
576 the processes and outcomes of these recent events. Further empirical examination of these

577 disruptive acts will offer unique opportunities to contribute to theory in general and explore

578 the interplay between actors, institutions, and logics specifically.

579

580

581

582

583

584

585

586

587

588

589

590

591

592

593

594

595

597

598

599

600

\section{Entrepreneurship}

A concept closely linked to institutional work is institutional entrepreneurship (Maguire et al., 2004). Institutional entrepreneurship refers to "the activities of actors who have an interest in particular institutional arrangements and who leverage resources to create institutions or transform existing ones" (Maguire et al., 2004, p. 657). This research domain emerged, in part, in response to the "paradox of embedded agency" problem which questions how it may be possible to be embedded within an institutional field whilst simultaneously able to shape it. Institutional entrepreneurs typically operate at micro-foundational level, "work" on the periphery as boundary-spanners and can leverage their unique political and social skills to enable institutional change.

Only a handful of studies $(n=10)$ have adopted the institutional entrepreneurship perspective. Researchers have utilized the sport context to provide more detailed analysis of the micro-foundational level of how entrepreneurs operate. This includes the antecedents, mechanisms, and outcomes of change (Lakshman \& Akhter, 2015) and how entrepreneurs can work to disrupt socially and ethically undesirable institutional practices (Khan et al., 2007). Collectively, the above studies have contributed to an agency-focused approach that helps explain how institutions can be created, maintained, and disrupted.

\section{Future Directions and Research Agenda}

This study sought to empirically review research that utilized institutional perspectives within the sport context. In reviewing the literature, our analysis identified 188 studies, revealing that sport, as an endeavor, is ripe to examine institutional phenomena. To work toward a joint venture between institutional theory more broadly, and sport management literature 
601 specifically, this section sets out to achieve two goals. Firstly, we identify gaps in our current understanding based on our review of sport related institutional studies. Secondly, we attempt to align these gaps in our knowledge with the current movements of institutional theory in mainstream management to provide directions for future research.

With regards to our findings more generally, it seems to be that the sport management

606 literature is following the movements of institutional theory more broadly. Thus, when the

607 institutional theory literature was dominated by concepts of legitimacy, isomorphism, and 608 change, so too was the sport management literature. However, once concepts such as logics and work were introduced to the institutional theory lexicon, so too did these concepts begin emerging in the sport management literature. In this way, building on Washington and

611 Patterson (2011), the relationship between sport and institutional theory does not appear to be 612 a joint venture or a hostile takeover, but instead a sort of diffusion of ideas. Like how a store 613 gets a cult following in one location and then expands into other locations, so too has

614 institutional theory developed a following in mainstream management's literature prior to 615 expanding into sport management.

616 We would like to advance the conversation from a diffusion of ideas, toward a joint 617 venture in which both mainstream- and sport- management "share in the costs and share in 618 the benefits" of institutional analysis in sport (Washington \& Patterson, 2011, p. 2). In Table

6191 we identify sites of shared value to act as foundations for such a joint venture. The first 620 column (left) summarizes the sport related institutional knowledge based on our review of the 621 extant literature. The second column (middle) encapsulates the main thrust of future research 622 directions proposed by leading institutional scholars in recent reviews of specific institutional 623 constructs. Finally, the third column combines gaps in our sport-related knowledge with 624 future research directions of institutional theory more broadly for the purpose of laying the 625 foundation for a stronger joint venture between institutional theory and sport in future. Sites 
626 of shared value should enable the pursuit of both derivate and sport-focussed models of

627 research (Chalip, 2006). The former locates sport as an empirical context to affirm, apply,

628 and advance mainstream theories (e.g., Lok \& de Rond, 2013). The latter creates or adapts

629 existing theory grounded in the phenomena of sport (e.g., Lock et al., 2015). We expand on

630 these sites of shared value below.

631 Table 1 - Summary of findings, future research directions and potential sites of shared value

632 for a joint venture

633

\begin{tabular}{|c|c|c|}
\hline Summary of findings & Future research directions & $\begin{array}{c}\text { Potential sites of shared } \\
\text { value }\end{array}$ \\
\hline $\begin{array}{l}\text { Legitimacy \& } \\
\text { Institutionalization } \\
\text { Researchers' have } \\
\text { primarily employed } \\
\text { pragmatic questions to } \\
\text { examine the utility of } \\
\text { legitimacy as a property } \\
\text { for sport organizations. } \\
\text { The process of gaining } \\
\text { or losing legitimacy, and } \\
\text { in particular the } \\
\text { perception or social } \\
\text { evaluation of sport } \\
\text { organizations legitimacy } \\
\text { are less understood. }\end{array}$ & $\begin{array}{l}\text { Derived from Deephouse et al } \\
\text { (2017). } \\
\text { (1) Critically review, integrate, } \\
\text { and consolidate different } \\
\text { approaches to verbal } \\
\text { legitimation tactics. } \\
\text { (2) Investigate how both symbolic } \\
\text { and substantive management } \\
\text { approaches influence } \\
\text { legitimacy judgements } \\
\text { (3) How do new governance } \\
\text { mechanisms develop and } \\
\text { maintain legitimacy? } \\
\text { (4) How does digital technology } \\
\text { affect legitimation? }\end{array}$ & $\begin{array}{l}\text { - How are verbal } \\
\text { legitimation tactics } \\
\text { used to justify } \\
\text { transgressive behavior } \\
\text { in sport? } \\
\text { - How are social } \\
\text { judgements (i.e., } \\
\text { perceptions) regarding } \\
\text { the legitimacy of sport } \\
\text { organizations formed } \\
\text { between different } \\
\text { stakeholder groups? } \\
\text { What processes of } \\
\text { legitimation and } \\
\text { institutionalization } \\
\text { have led international } \\
\text { sport organizations to } \\
\text { develop and maintain } \\
\text { degrees of self- } \\
\text { governance? }\end{array}$ \\
\hline $\begin{array}{l}\text { Change } \\
\text { Change was present } \\
\text { within and across all our } \\
\text { institutional constructs. } \\
\text { Our analysis indicated a } \\
\text { shift away from } \\
\text { organizational change } \\
\text { towards institutional } \\
\text { change in recent years. } \\
\text { Revolutionary top-down } \\
\text { changes in which logics } \\
\text { have either displaced or } \\
\text { come to co-exist with }\end{array}$ & $\begin{array}{l}\text { Derived from Micelotta et al } \\
\text { (2017). } \\
\text { (5) How is transformative change } \\
\text { influenced by field pluralism? } \\
\text { (6) How is balance between } \\
\text { multiple logics negotiated and } \\
\text { maintained in complex } \\
\text { organizations? } \\
\text { (7) How do institutional } \\
\text { entrepreneurs craft } \\
\text { legitimation strategies and } \\
\text { articulate frames that resonate }\end{array}$ & $\begin{array}{l}\text { - How do national sport } \\
\text { organizations } \\
\text { operating } \\
\text { simultaneously in } \\
\text { multiple fields, } \\
\text { institutionalize } \\
\text { transformative } \\
\text { change? } \\
\text { - How can institutional } \\
\text { change help us } \\
\text { understand social } \\
\text { change in sport? } \\
\text { In what ways can } \\
\text { micro-social practices }\end{array}$ \\
\hline
\end{tabular}




\begin{tabular}{|c|c|c|}
\hline $\begin{array}{l}\text { other logics have } \\
\text { dominated the change } \\
\text { literature (e.g., the } \\
\text { professionalization of } \\
\text { amateur sports). Less } \\
\text { understood is } \\
\text { evolutionary, bottom-up } \\
\text { change in which } \\
\text { individuals and micro- } \\
\text { processes change }\end{array}$ & $\begin{array}{l}\text { with culturally heterogeneous } \\
\text { audiences? } \\
\text { (8) Under what conditions do } \\
\text { micro-level acts of } \\
\text { improvisations stimulate } \\
\text { broader field-level } \\
\text { transformations? }\end{array}$ & $\begin{array}{l}\text { (e.g., kneeling) lead to } \\
\text { institutional change in } \\
\text { sport? } \\
\text { - How are sport policies } \\
\text { translated between } \\
\text { national, regional, and } \\
\text { local levels? }\end{array}$ \\
\hline $\begin{array}{l}\text { Isomorphism } \\
\text { Isomorphism studies } \\
\text { have become relatively } \\
\text { less frequent in the last } \\
\text { decade. Most studies } \\
\text { conducted utilized } \\
\text { DiMaggio and Powell's } \\
\text { (1983) three isomorphic } \\
\text { pressures: mimetic } \\
\text { processes, normative } \\
\text { pressures, and coercive } \\
\text { isomorphism and in line } \\
\text { with mainstream } \\
\text { literature found that } \\
\text { organizations became } \\
\text { increasingly similar } \\
\text { within the same field. }\end{array}$ & $\begin{array}{l}\text { Derived from Heugens and } \\
\text { Lander (2009). } \\
\text { - Through what processes do } \\
\text { organizations experience, } \\
\text { interpret, and manage } \\
\text { isomorphic pressures? } \\
\text { - What field level mechanisms } \\
\text { accelerate and coordinate } \\
\text { collective organizational } \\
\text { action? } \\
\text { - How do micro sociological } \\
\text { processes (i.e., agency) } \\
\text { interact with isomorphic } \\
\text { pressures? }\end{array}$ & $\begin{array}{l}\text { - How does symbolic } \\
\text { isomorphism to the } \\
\text { sport ethic influence } \\
\text { the substantive } \\
\text { performance of sport } \\
\text { organizations? } \\
\text { - What field level } \\
\text { mechanisms lead to } \\
\text { 'breaking the iron } \\
\text { cage' and the adoption } \\
\text { of non-conforming } \\
\text { organizational } \\
\text { templates in sport } \\
\text { organizations? } \\
\text { Does field } \\
\text { structuration of a sport } \\
\text { influence isomorphic } \\
\text { mechanisms? }\end{array}$ \\
\hline $\begin{array}{l}\text { Logics } \\
\text { Many studies examined } \\
\text { binary logics that } \\
\text { contrasted forms of } \\
\text { commercial sport logics } \\
\text { (i.e., professionalization, } \\
\text { elite, business ideals) } \\
\text { with forms of voluntary } \\
\text { sport logics (i.e., play, } \\
\text { participation, } \\
\text { amateurism ideals). } \\
\text { Logic studies primarily } \\
\text { focused on how a once } \\
\text { dominant logic came to } \\
\text { accommodate a new } \\
\text { logic into their } \\
\text { organizational meaning } \\
\text { systems and decision- } \\
\text { making processes. }\end{array}$ & $\begin{array}{l}\text { Derived from Ocasio et al (2017). } \\
\text { How do actors influence the } \\
\text { micro foundations of } \\
\text { institutional logics? } \\
\text { How do organizations assess } \\
\text { and activate logics from the } \\
\text { multiple logic systems that are } \\
\text { available to them? } \\
\text { Under what conditions are } \\
\text { actors able to invoke or } \\
\text { combine different logics, and } \\
\text { with what effects? }\end{array}$ & $\begin{array}{l}\text { By what processes do } \\
\text { sport organizations } \\
\text { assess and activate } \\
\text { logics within complex } \\
\text { stakeholder } \\
\text { environments? } \\
\text { - Do different logic } \\
\text { systems exist between } \\
\text { similar sports? If so, } \\
\text { why? } \\
\text { - How has the } \\
\text { combination of logics } \\
\text { over time influenced } \\
\text { the field structures and } \\
\text { individual agency } \\
\text { within given sports? } \\
\text { Do athlete behaviors, } \\
\text { over time, transform } \\
\text { institutional logics? }\end{array}$ \\
\hline
\end{tabular}




\begin{tabular}{|c|c|c|}
\hline $\begin{array}{l}\text { Fields } \\
\text { Many studies used fields } \\
\text { as a conceptual boundary } \\
\text { condition, rather than as } \\
\text { a focal unit of analysis. } \\
\text { A paucity of research on } \\
\text { the origin and } \\
\text { structuration of fields } \\
\text { was identified. Sport has } \\
\text { advanced our } \\
\text { understanding of nested } \\
\text { fields and provides a } \\
\text { useful basis for the } \\
\text { examination of } \\
\text { multilevel institutional } \\
\text { change }\end{array}$ & $\begin{array}{l}\text { Derived from Zietsma et al., } \\
\text { (2017). } \\
\text { - What is the pace, sequence, } \\
\text { and linearity of field changes? } \\
\text { - How do organizations manage } \\
\text { connections to multiple fields } \\
\text { (i.e., those organizations in } \\
\text { interstitial positions)? } \\
\text { - What are the effects of field- } \\
\text { to-field interactions on the } \\
\text { structuration of respective } \\
\text { fields? } \\
\text { - How can issue fields influence } \\
\text { the creation of institutional } \\
\text { infrastructure to address } \\
\text { societal problems? }\end{array}$ & $\begin{array}{l}\text { - By what mechanisms } \\
\text { and processes does } \\
\text { multilevel change } \\
\text { occur within nested } \\
\text { fields in sport? } \\
\text { - How do social } \\
\text { activists influence } \\
\text { field dynamics in } \\
\text { sport? } \\
\text { - What is the role of } \\
\text { proto institutions in } \\
\text { field development in } \\
\text { sport? } \\
\text { - How has the pace, } \\
\text { sequence and linearity } \\
\text { of sport policy } \\
\text { adoption differed } \\
\text { between sports? }\end{array}$ \\
\hline $\begin{array}{l}\text { The main findings } \\
\text { indicated that } \\
\text { preliminary work had } \\
\text { been completed in the } \\
\text { areas of creation and } \\
\text { maintenance, however } \\
\text { there was yet to be any } \\
\text { studies completed in the } \\
\text { area of institutional } \\
\text { disruption. This may be } \\
\text { because of sport's rigid } \\
\text { institutional } \\
\text { arrangements and the } \\
\text { difficulties actors within } \\
\text { sport can have in } \\
\text { disrupting institutional }\end{array}$ & $\begin{array}{l}\text { Derived from Hampel et al. } \\
\text { (2017). } \\
\text { - How does institutional work } \\
\text { influence 'big' societal } \\
\text { institutions (i.e., those beyond } \\
\text { organizations and fields)? } \\
\text { - When, why, and how do } \\
\text { networks of heterogeneous } \\
\text { actors work together to shape } \\
\text { institutions? } \\
\text { - How does institutional work } \\
\text { relate to material objects such } \\
\text { as new technologies? } \\
\text { - How does institutional work } \\
\text { shape policy and practice to } \\
\text { address the world's grand } \\
\text { challenges? }\end{array}$ & $\begin{array}{l}\text { - Given the mass media } \\
\text { distribution of sport, } \\
\text { how can high profile } \\
\text { athletes and sport } \\
\text { organizations } \\
\text { influence societal } \\
\text { institutions? } \\
\text { - How has new } \\
\text { technology influenced } \\
\text { the institutional work } \\
\text { performed by sport } \\
\text { managers? } \\
\text { To what extent do } \\
\text { microsocial behaviors } \\
\text { (e.g., passion, } \\
\text { emotion) influence } \\
\text { institutional work in } \\
\text { the context of sport? }\end{array}$ \\
\hline
\end{tabular}

636 work on legitimacy has focussed on legitimacy as an organizational property, a resource or

637 asset that sport organizations gain or lose. Less research has investigated the process of how

638 legitimacy is constructed, or the way the legitimacy of sport organizations is perceived or 
640 to integrate and consolidate different types of verbal legitimation tactics due to the highly

641 publicized and chronicled audio-visual content (e.g., sport commentary, press conferences,

642 government debates) and legitimacy struggles (e.g., doping, violence, match-fixing, race, and

643 gender issues). Analysing such content over a period of time could yield new theoretical

644 insights into the tactics used by institutional entrepreneurs to legitimate actions within the

645 field of sport. A second avenue for future research in the legitimacy domain, may be to

646 further the work of Lock et al. (2015) who developed the Capture Perceptions of (Sport)

647 Organizations Legitimacy framework to examine social judgements of an Australian

648 community sport organization. Expanding and testing this tool in new contexts could inform

649 the strategic legitimation efforts of sport organizations more broadly. Given that legitimacy

650 has 'a clear effect on social and economic exchanges' (Deephouse et al., 2017, p. 34) and the

651 social judgements of constituent groups are socially constructed and context dependent, the

652 expansion of this type of work to different types of sport organizations (e.g., international

653 federations, professional teams, sponsors, national sport organizations) could open up a range

654 of future research opportunities.

655 Change was omnipresent within the sport related institutional literature and within our

656 institutional constructs. Our findings indicated a shift away from focusing on the narrow

657 concept of organizational change, toward the broader concept of institutional change.

658 Building upon the observation that sport often leads discussions of societal change,

659 institutional scholars in sport could engage in the grand challenges research program as a way

660 of investigating the influence of sport on social change in broader societal institutions. As

661 institutional studies on race (e.g., Agyemang et al,, 2018), inclusion (e.g., Robertson et al.,

662 2019), diversity (e.g., Cunningham, 2009), concussion (e.g., Heinze \& Lu, 2017), sexual

663 abuse (e.g., Nite \& Nauright, 2020), child labor (Khan et al., 2007), and doping (Read et al, 
2019) all indicate, institutional theory can be a powerful lens from which to investigate some

665

666

667

668

669

670

671

672

673

674

675

676

677

678

679

680

681

682

683

684

685

686

687

688 of sport, management, and society's grandest challenges.

Like the construct itself, research in sport studies using isomorphism were found to be relatively similar and generally aligned with forms of testing DiMaggio and Powell's (1983) original hypotheses. Heugens and Lander's (2009, p. 78) meta-analysis of 144 isomorphism studies concluded conformity with isomorphic pressures increased the symbolic performance of organizations. However small average effect sizes $(0.07$ for coercive and normative pressures and 0.09 for mimetic pressures) indicated relatively weak isomorphic forces and hardly the inescapable iron cage that early structural determinists presented as a stylized fact of organizational life. Consequently, whilst there is some theoretical meat left on proverbial isomorphism bone, scholars need to be careful not to replicate what is known. One area of promise, highlighted by Greenwood and Meyer (2008) is the investigation of power and politics, and the degree of heterogeneity between organizations. They suggest that given variance in 'field structuration,' 'complex institutional arrangements,' and 'multiple institutional prescriptions' a more nuanced and multidimensional exploration of the degree of similarity may be warranted (p. 263). One way this may be approached within sport studies is to treat isomorphic mechanisms as "categories of mechanisms, not variables with specific effects, and focus on how these mechanisms operate" (Washington \& Ventresca, 2004, p. 93). Linking isomorphic mechanisms to agents (e.g., powerful elites) or historical field structuring events (e.g., broadcast rights deals) could inform a more structural view of institutional change that has been relegated in institutional scholarship following the agency turn with its associated focus on actors, actions, and micro-social processes.

Logic studies generally investigated versions of the binary logics that contrasted forms of commercial sport logics (i.e., professionalization, elite, business ideals) with forms of voluntary sport logics (i.e., play, participation, amateurism ideals). These studies often 
689 discussed two types of logic multiplicity, (1) where two logics lacked compatibility within a

690 single organization, and hence existed in a state of tension or conflict, or (2) how an existing

691 logic was displaced by a new logic. Rarely did logic studies investigate other types of logic

692 multiplicity such as the relationships between peripheral and dominant logics, or where

693 central logics were highly compatible (c.f. Besharov \& Smith, 2014). Additionally, with few

694 exceptions (c.f., Borgers et al., 2019; Fahlen \& Stenling, 2019), institutional logics and

695 change have been investigated from a top-down perspective in which changing logics at 696 societal, field, or organizational level influence forms of alignment and accommodation of

697 logics at lower levels. What is less well understood is how these changes can occur from a

698 bottom-up perspective, or how existing institutional arrangements can be slowly transformed

699 by the aggregation of micro-social processes. Given sports relative rigid institutional logic

700 systems, a view toward how micro-social processes transform field level logics over time may be a beneficial future research avenue.

Our research aligned with Washington and Patterson's (2011) observation that the organizational (or institutional) field construct, seems to be the one construct that has not diffused as much as the others (less than $8 \%$ of all studies, but having been around since 2000). Potentially this could be attributed to the fact that most published sport studies only examine one sport (or one organization, association, etc.) at a time. Whereas organizational

707 field studies tend to study movements of broader activities that are nested across multiple organizations. A particular limitation of many field studies we observed was the use of fields as a tool for delimiting the contextual boundary for studies focussing on other institutional

710 constructs (e.g., logics or isomorphism), as opposed to 'saying something' about the field itself. Within those studies that have been undertaken, our analysis specifically revealed a lack of research on the origin and structuration of fields. This has implications in three ways.

713 Firstly, how field formation relates to institutionalization and legitimation of fields/sports at 
714 inception. Secondly, as Washington (2004) demonstrated, fields merge, split, grow, and

715 decline over time. Many major sport institutions around the world formed based on combining fields. Third, the structuration of fields can influence how symbolic and material

717 resources are distributed, how norms are formed, and what type of actors have power relative

718 to the accepted norms and values of the field. Better understanding the historical

719 development of, and structuration processes within fields, could help us more accurately

720 develop an understanding of how modern sport came to be, and why certain groups hold 721 decision making power.

Our final call for future research is a call for a continued divergence between institutional work and other notions of institutional change. Our findings broadly align with Nite and Edwards (2021) review of institutional work literature in sport management, in particular their call for a stronger integration of institutional work with other core institutional constructs (particularly fields, legitimacy, and logics). As institutional scholarship increasingly focusses on agency, there is a heightened need to bring micro sociological approaches back into institutional theory, and in doing so link these with existing institutional constructs which better explain macro sociological phenomena. Given the applied focus of sport management, it is hardly surprising that sport scholars have gravitated to institutional work to explain the changing arrangements within sport. We feel there are opportunities for investigating how individuals in sport can influence society. If 2020 has taught us anything, it is that sport might be the first place where societal institutions are de-institutionalized or

734 disrupted. Sport leagues were one of the first professions to shut down during the onset of

735 COVID-19 and empty stadia became one of the iconic symbols of changed societal

736 institutions impacted by COVID-19. The Black Lives Matter protests not only almost 737 disrupted the restart of those leagues, but it also reverberated across the globe. In addition, 738 delving deeper into the psychological mechanisms (e.g., passion, emotion) and field location 
(e.g., central, middle status, and peripheral) of actors may also help advance institutional theory in the sport context. Moreover, this line of research has the potential to further develop concepts of institutional entrepreneurship and institutional leadership.

(e.g., leadership, emotions, perceptions of legitimacy etc.). This suggests that just like institutions change, so too will the institutional theory studies that are published in sport management (albeit with lots of work and slowly). We only hope that with the maturation of institutional theory in the sport management literature that there are enough gatekeepers (editors and reviewers) that are equally aware of these newer concepts and do not constrain contemporary institutional scholarship to the 1980 s version of institutional theory.

Recognizing institutional theory's explanatory potential, it is incumbent on scholars to see beyond the theory's historical beginnings and utilize the wide variety of perspectives that contemporary institutional scholarship offers.

\section{Conclusion} review types such as systematic reviews or meta-analyses. Firstly, scoping reviews do not assess the quality of the studies included in the review, nor are they as exhaustive as traditional systematic reviews. Secondly, the homonymous nature of the term institution (and its derivatives) in combination with multiple types of institutionalism (i.e., political, economic - see Hall \& Taylor, 1996) make the conceptual boundaries of any search, at best, porous. Whilst we included an additional evaluation stage that involved an ancestry search of

761 all citations in our analysis to identify any boundary spanners to minimize this limitation, we do not claim that our review is an exhaustive representation of studies that have utilized institutional theory in sport. Finally, common limitations in scoping reviews were also 
764

765

766

767

768

769

770

771

772

773

774

775

776

777

778

779

780

781

782

783

784

785

786

787

788

apparent in our study. For example, whilst we have made efforts to include the seminal books of the field in general, such as the orange (Powell \& DiMaggio, 1991) and green books (Greenwood et al., 2008; 2017), our search only included journal articles written in English. Institutional theory has become one of the central theoretical perspectives in sport studies. Contemporary institutional theory now covers a vast territory, from individual agency to world society. Despite this, no structured empirical review of this literature had been attempted. This is an important oversight for a discipline wishing to theoretically advance as an academic field, and practically influence the provision of sport. By providing an empirical review of institutional theory in sport we hope to expediate the diffusion of ideas between mainstream- and sport- management in the hopes of realising the collective benefits of a joint venture in the future.

This scoping review has advanced Washington and Patterson's (2011) study by systematically reviewing and consolidating sport related institutional studies. Institutional theory can be a daunting theoretical landscape for new (and experienced) scholars to enter. By reviewing the literature (see appendix 1) we hope to have contributed in a small way to advancing the accessibility of contemporary institutional theories as they relate to sport. Our second contribution looked to map the extant literature into conceptual groups. By outlining and classifying the notable features of the theoretical landscape (Figure 2), our hope is that scholars are more able to easily navigate their way through the institutional terrain.

Our third contribution was to demonstrate the growth, breadth, and development of institutional theory in sport (Figure 1). Institutional theory is not singular, but rather a composite of theoretical viewpoints, the major constructs of which were analyzed in this study. Our final contribution was the development of a road map for future research (Table 1). In the decade since Washington and Patterson's (2011) study, the number of studies that have used institutional theory in sport have more than doubled. Consequently, the theoretical 
789 landscape is substantively different now, then it was then. By providing a clear road map for

790 future research, with signposts to contemporary reviews, we hope to expediate diffusion of

791 ideas between mainstream- and sport- management.

792

793

794

813 Bourdieu, P. (1977). Outline of a theory of practice. Polity Press.

814 Bourdieu, P. (1990). The logic of practice. Polity Press.

\section{References} Management, 32(6), 567-580. Academy of Management Journal, 47(1), 15-39. International Journal of Social Research Methodology, 8(1), 19-32. 107. $8(5), 492-510$. 381. for the Sociology of Sport, 53(1), 84-100.

*Agyemang, K., Berg, B., \& Fuller, R. (2018). Disrupting the disruptor: Perceptions as institutional maintenance work at the 1968 Olympic Games. Journal of Sport

*Amis, J., Slack, T., \& Hinings, B. (2004). The pace, sequence, and linearity of radical change.

Arksey, H., \& O’Malley, L. (2005). Scoping studies: Towards a methodological framework.

Battilana, J., Leca, B., \& Boxenbaum, E. (2009). How actors change institutions: Towards a theory of institutional entrepreneurship. Academy of Management Annals, 3(1), 65-

*Batuev, M. \& Robinson, L. (2018). What influences organizational evolution of modern sport: The case of skateboarding. Sport, Business and Management: An International Journal,

Besharov, M., \& Smith, W. (2014). Multiple Institutional Logics in Organizations: Explaining Their Varied Nature and Implications', Academy of Management Review, 39(3), 364-

*Borgers, J., Pilgaard, M., \& Vanreusel, B. (2018). Can we consider changes in sports participation as institutional change? A conceptual framework. International Review 
815 Campbell, J. L. (2004). Institutional change and globalization. Princeton University Press.

816 Chalip, L. (2006). Toward a distinctive sport management discipline. Journal of Sport Management, 20(1), 1-21

*Cousens, L., \& Slack, T. (2005). Field-level change: The case of North American major league professional sport. Journal of Sport Management, 19(1), 13-42.

*Cunningham, G. (2009). Understanding the diversity-related change process: A field study. Journal of Sport Management, 23(4), 407-428.

Deephouse, D., Bundy, J., Tost, L., \& Suchman, M. (2017). Organizational legitimacy: Six key questions. In R. Greenwood, C. Oliver, R. Lawrence \& R. Meyer (Eds.), The SAGE handbook of organizational institutionalism (pp. 28-54). SAGE.

DiMaggio, P. (1988). Interest and agency in institutional theory. In L. Zucker (Ed.), Institutional patterns and organizations (pp. 3-22). Ballinger.

DiMaggio, P., \& Powell, W. (1983). The iron cage revisited: Institutional isomorphism and collective rationality in organizational fields. American Sociological Review, 48(2), $147-160$.

DiMaggio, P., \& Powell, W. (1991). The new institutionalism and organizational analysis. University of Chicago Press.

Dowling, M., Leopkey, B., Inoue, Y., Berg, B.K., \& Smith, L. (2020). Scoping reviews and structured research synthesis in sport: methods, protocol and lessons learnt. International Journal of Sport Policy and Politics, 12(4), 765-774.

*Dowling, M., \& Smith, J. (2016). The institutional work of Own the Podium in developing high-performance sport in Canada. Journal of Sport Management, 30(4), 396-410.

Durand, R., \& Thornton, P. (2018). Categorizing institutional logics, institutionalizing 658. 
840

841

842

843

844

845

846

847

848

849

850

851

852

853

854

855

856

857

858

859

860

861

862

863

864

*Ellis, D., \& Parent, M., \& Seguin, B. (2016). Olympic ambush marketing networks and knowledge transfer: Examining their impact on the institutionalization of anti-ambush marketing legislation. Journal of Sport Management, 30(5), 473-489.

*Fahlén, J., \& Stenling, C. (2019). (Re)conceptualizing institutional change in sport management contexts: the unintended consequences of sport organizations' everyday organizational life. European Sport Management Quarterly, 19(2), 265-285.

Friedland, R., \& Alford, R. (1991). Bringing society back in: Symbols, practices, and institutional contradictions. In W. Powell \& P. DiMaggio (Eds.), The new institutionalism in organizational analysis (pp. 232-263). University of Chicago Press.

*Gammelsæter, H. (2010). Institutional pluralism and governance in "commercialized" sport clubs. European Sport Management Quarterly, 10(5), 569-594.

*Gérard, S., Legg, D., \& Zintz, T. (2017). Multi-level analysis of institutional formation and change: The case of the Paralympic movement. Sport, Business and Management: An International Journal, 7(5), 515-541.

*Girginov, V., \& Sandanski., I. (2008). Understanding the changing nature of sports organizations in transforming societies. Sport Management Review, 11(1), 21-50.

Greenwood, R., \& Hinings, C. R. (1988). Organizational design types, tracks, and dynamics of strategic change. Organization Studies, 9(3), 293-316.

Greenwood, R., \& Meyer, R. (2008). Influencing Ideas: A celebration of DiMaggio and Powell (1983). Journal of Management Inquiry, 17(4), 258-264.

Greenwood, R., Oliver, C., Sahlin, K., \& Suddaby, R. (2008). SAGE handbook of organizational institutionalism. SAGE.

Greenwood., R, Oliver, C., Lawrence, T., \& Meyer, R. (2017). Introduction: Into the fourth decade. In R. Greenwood, C. Oliver, R. Lawrence \& R. Meyer (Eds.), The SAGE handbook of organizational institutionalism (pp. 1-24). SAGE. 
865 Hall, P., \& Taylor, R., (1996). Political science and the three new institutionalisms. Political Studies, 44(5), 936-57.

Hampel, C., Lawrence, T., \& Tracey., P. (2017). Institutional work: Taking stock and making it matter. In R. Greenwood, C. Oliver, R. Lawrence \& R. Meyer (Eds.), The SAGE handbook of organizational institutionalism (pp. 558-590). SAGE.

Hargrave, T., \& Van de Ven, A. (2006). A collective action model of institutional innovation. Academy of Management Review, 31(4), 864-888.

*Heinze, K., \& Lu, D. (2017). Shifting responses to institutional change: The National Football League and player concussions. Journal of Sport Management, 31(5), 497-513.

*Helms, W., \& Patterson, K. (2014). Eliciting acceptance for "illicit" organizations: The positive implications of stigma for MMA organizations. Academy of Management Journal, 57(5), 1453-1484.

*Hemme, F., \& Morais, D. (2021). Legitimacy in public recreation: examining rhetorical shifts in institutional creation and maintenance. Sport in Society, 24(2), 160-80.

Heugens, P., \& Lander, M. (2009). Structure! Agency! (and other quarrels): A meta-analysis of institutional theories of organization. Academy of Management Journal, 52(1), 6185.

*Hoibian, O. (2006). Sociogenesis of a social field: The cultural world of mountaineering in France from 1870 to 1930. International Review for the Sociology of Sport, 41(3-4), 339-355.

*Khan, F., Munir, K., \& Willmott, H. (2007). A dark side of institutional entrepreneurship: Soccer balls, child labour and postcolonial impoverishment. Organization Studies, 28(7), 1055-1077. 
888

889

890

891

892

893

894

895

896

897

898

899

900

901

902

903

904

905

906

907

908

909

910

911

912

*Kikulis, L. (2000). Continuity and change in governance and decision making in national sport organizations: Institutional explanations. Journal of Sport Management, 14(4), 293-320.

*Kikulis, L., Slack, T., \& Hinings, B. (1992). Institutionally specific design archetypes: A framework for understanding change in national sport organizations. International Review for the Sociology of Sport, 27(4), 343-368.

Kitchin, P., \& Howe, P. (2013). How can the social theory of Pierre Bourdieu assist sport management research? Sport Management Review, 16(2), 123-134.

*Lakshman, C., \& Akhter, M. (2015). Microfoundations of institutional change: Contrasting institutional sabotage to entrepreneurship. Canadian Journal of Administrative Sciences, 32(3), 160-176.

Laughlin, R. (1991). Environmental disturbances and organizational transitions and transformations: Some alternative models. Organizational Studies, 12(2), 209-232.

Lawrence, T., \& Suddaby, R. (2006). Institutions and institutional work. In S. Clegg, C. Hardy, T. Lawrence, \& W. Nord (Eds.), Handbook of organization studies (pp. 215-254). SAGE.

*Leopkey, B., \& Parent, M. (2012). The (Neo) institutionalization of legacy and its sustainable governance within the Olympic Movement. European Sport Management Quarterly, $12(5), 437-455$.

*Lock, D., Filo, K., Kunkel, T., \& Skinner, J. (2015). The development of a framework to capture perceptions of sport organizations legitimacy. Journal of Sport Management, 29(4), 362-379.

*Lok, J., \& de Rond, M. (2013). On the plasticity of institutions: Containing and restoring practice breakdowns at the Cambridge University Boat Club. Academy of Management Journal, 56(1), 185-207. 
913 Lounsbury, M., Ocasio, W., \& Thornton, P. (2017). The multiplicity of institutional logics. European Group for Organizational Studies. https://www.egosnet.org/jart/prj3/egos/main.jart?rel=de\&reserve$\underline{\text { mode }=\text { active } \& \text { content }-i d=1442567999321 \& \text { subtheme } \mathrm{id}=1442568028828}$

Maguire, S., Hardy, C., \& Lawrence, T.B. (2004). Institutional entrepreneurship in emerging fields: HIV/AIDS treatment advocacy in Canada. Academy of Management Journal, 47(5), 657-679.

Meyer, J., \& Rowan, B. (1977). Institutional organizations: Formal structure as myth and 921 ceremony. American Journal of Sociology, 83(2), 340-363.

Micelotta, E., Lounsbury, M., \& Greenwood, R. (2017). Pathways of institutional change: An integrative review and research agenda. Journal of Management, 43(6), 1885-1910.

*Nite, C. (2017). Message framing as institutional maintenance: The National Collegiate 925 Athletic Association's institutional work of addressing legitimate threats. Sport Management Review, 20(4), 338-351.

Nite, C., \& Edwards, J. (2021). From isomorphism to institutional work: Advancing institutional theory in sport management research. Sport Management Review, DOI: $10.1080 / 14413523.2021 .1896845$

931

*Nite, C., Ige, A., \& Washington, M. (2019). The evolving institutional work of the National Collegiate Athletic Association to maintain dominance in a fragmented field. Sport Management Review, 22(3), 379-394.

*Nite, C. \& Nauright, J. (2020). Examining institutional work that perpetuates abuse in sport organizations Sport Management Review, 23(1), 117-29.

*O'Brien, D., \& Slack, T. (1999). Deinstitutionalising the amateur ethic: An empirical examination of change in a rugby union football club. Sport Management Review, 2(1), 
938

939

940

941

942

943

944

945

946

947

948

949

950

951

952

953

954

955

956

957

958

959

960

*O'Brien, D., \& Slack, T. (2003). An analysis of change in an organizational field: The professionalization of English rugby union. Journal of Sport Management, 17(4), 417448.

Ocasio, W., Thornton, P., \& Lounsbury, M. (2017). Advances to the institutional logics perspective. In R. Greenwood, C. Oliver, R. Lawrence \& R. Meyer (Eds.), The SAGE handbook of organizational institutionalism (pp. 509-31). SAGE.

*Pedras, L., Taylor, T., \& Frawley, S. (2020). Responses to multi-level institutional complexity in a national sport federation. Sport Management Review, 23(3), 482-497.

Pettigrew, A. (1987). Context and action in the transformation of the firm. Journal of Management Studies, 24(6), 649-670.

*Read, D., Skinner, J., Lock, D., \& Houlihan, B. (2019). Legitimacy driven change at the World Anti-Doping Agency. International Journal of Sport Policy and Politics, 11(2), 233-245.

Robertson, J., Storr, R., Bakos, A., \& O’Brien, D. (2019). “My ideal is where it is just Jane the cricketer, rather than Jane the gay cricketer": An institutional perspective of lesbian inclusion in Australian cricket. Journal of Sport Management, 33(5), 393-405.

Scott, W. (1995/2014). Institutions and organizations. ( $1^{\text {st }} / 4^{\text {th }}$ eds.) SAGE.

*Skille, E. (2011). Change and isomorphism - A case study of translation processes in a Norwegian sport club. Sport Management Review, 14(1), 79-88.

*Skirstad, B., \& Chelladurai, P. (2011). For 'love' and money: A sports club's innovative response to multiple logics. Journal of Sport Management, 25(4), 339-353.

*Slack, T. \& Hinings, B. (1994). Institutional pressures and isomorphic change: An empirical test. Organization Studies, 15(6), 803-827. 
961

962

963

964

965

966

967

968

969

970

971

972

973

974

975

976

977

978

979

980

981

982

983

*Southall, R., Nagel, M., Amis, J., \& Southall, C. (2008). A method to March Madness? Institutional logics and the 2006 National Collegiate Athletic Association division men's basketball tournament. Journal of Sport Management, 22(6), 677-700.

*Stenling, C. \& Sam, M. (2017). Tensions and contradictions in sport's quest for legitimacy as a political actor: the politics of Swedish public sport policy hearings. International Journal of Sport Policy and Politics, 9(4), 691-705.

Suddaby, R., Bitektine, A., \& Haack, P. (2017). Legitimacy. Academy of Management Annals, $11(1), 451-478$.

*Svensson, P. (2017). Organizational hybridity: A conceptualization of how sport for development and peace organizations respond to divergent institutional demands. Sport Management Review, 20(5), 443-454.

Thornton, P., \& Ocasio, W. (1999). Institutional logics and the historical contingency of power in organizations: Executive succession in the higher education publishing industry, 1958-1990. The American Journal of Sociology, 105(3), 801-843.

Thornton, P., \& Ocasio, W. (2008). Institutional logics. In R. Greenwood, C. Oliver, K. Sahlin \& R. Suddaby, (Eds.), The SAGE handbook of organizational institutionalism (pp. 99129). SAGE.

Tricco, A., Lillie, E., Zarin, W., O’Brien, K., ... Straus, S. (2018). PRISMA extension for scoping reviews (PRISMA-ScR): checklist and explanation. Annals of Internal Medicine, 169(7), 467-473.

*Washington, M. (2004). Field approaches to institutional change: The evolution of the National Collegiate Athletic Association 1906-1995. Organization Studies, 25(3), 393414. 
984

985

986

987

988

989

990

991

992

993

994

995

996

997

998

999

1000

1001

1002

1003

1004

1005

*Washington, M., \& Ventresca, M. (2004). How organizations change: The role of institutional support mechanisms in the incorporation of higher education visibility strategies, 18741995. Organization Science, 15(1), 82-97.

*Washington, M., \& Ventresca, M. (2008). Institutional contradictions and struggles in the formation of U.S. collegiate basketball, 1880-1938. Journal of Sport Management, $22(1), 30-49$.

*Washington, M., \& Patterson, K. (2011). Hostile takeover or joint venture: Connections between institutional theory and sport management research. Sport Management Review, 14(1), 1-12.

*Woolf, J., Berg, B., Newland, B., \& Green, C. (2016). So you want to be a fighter? Institutional work and sport development processes at an elite mixed martial arts gym. Journal of Sport Management, 30(4), 438-452.

*Wright, A. (2009). Domination in organizational fields: It's just not cricket. Organization, 16 (6), 855-885.

*Wright, A., \& Zammuto, R. (2013). Wielding the willow: Processes of institutional change in English County Cricket. Academy of Management Journal, 56(1), 308-330.

*Zakus, D., \& Skinner, J. (2008). Modelling organizational change in the International Olympic Committee. European Sport Management Quarterly, 8(4), 421-442.

Zietsma, C., Groenewegen, P., Logue, D., \& Hinings, B. (2017) Field or fields? Building the scaffolding for cumulation of research on institutional fields. Academy of Management Annals, 11(1), 391-450.

\footnotetext{
* Indicates included in our review
} 